\title{
PRODUCTION AND EVALUATION OF DATE-SKIM MILK POWDER
}

(Received: 27.1.2009)

\author{
By \\ M.T.M. Assous, Neamah R.Attalla* and Eman F. Mohamed" \\ Food Technology Research Institute, Agricultural Research Center, Giza,Egypt \\ *Animal Production Research Institute, Agricultural Research Center,Giza,Egypt.
}

\begin{abstract}
This study was carried out to produce date-skim milk powders rich in sugars, proteins and minerals. Factors affecting the physical, chemical, sensory, microbiological properties and quality of the products were studied after processing and during storage.

Results indicated that the best mixtures were at a ratio of 1: 1 and1: 2 from date or date extract: skim milk powder regardless of the product type. Total sugars, protein and ash contents of the products ranged from 47.85 to $65.95,14.38$ to 27.66 and 3.92 to $7.59 \%$, respectively (on dry weight basis) and caloric value of the products ranged from 361.23 to $367.26 \mathrm{cal} / 100 \mathrm{~g}$.

Essential amino acids composition of the new products was high especially leucine, lysine, isoleucine, phenylalanine and valine, and non essential amino acids such as glutamic acid, aspartic acid and proline. Also, the present results indicated that the products are good source of many important elements such as potassium, calcium, sodium and phosphorus.

The chemical composition of the products was slightly affected by storage, while statistical analyses for sensory evaluation of the products showed that they were accepted till 9 months of storage at room temperature $\left(25^{\circ} \mathrm{C}\right)$.
\end{abstract}

Key words: date- skim milk powder, production,storage.

\section{INTRODUCTION}

Date fruit is a highly nutritious food product, rich in calories, many vitamins and minerals. Date fruits, are exceptionally rich in potassium and extremely low in sodium which is a desirable food for hypertensive persons who are advised to consume low sodium diets. Increase in date fruit production will, therefore, play the nutritional status of people, with special references to calories and the important minerals (Yousif et al., 1976 and Al-Hooti et al., 2002).

Sorour and Assous (2008) reported that total sugars, non-reducing and reducing sugars, crude fiber and ash content of siwi date at the tamr stage were $90.77,89.49$ and $1.28,3.08$ and $2.06 \%$ on dry weight basis, respectively. Also, Khalil et al., (2002) reported that total sugars represent the major constitute of the soluble solids content and reducing sugars were $~ 90 \%$ of the total sugars of siwi dates. The chemical composition of date shows that the flesh is an important source of sugars ( $81-88 \%$, mainly fructose, glucose and sucrose), dietary fiber ( $\sim 5-8.5 \%)$ and small amount of protein, and fat (Elleuch et al., 2008).

Dates are not a major source of protein since they contain protein levels about $1.5-2.0 \%$ by weight (Vandercook et al., 1979). Health and disease are primarily due to deficiency of protein in the diet, and often associated with lack of calories (Ramadan, 1995).

Fortification of dates with rich foods, which have high protein, mineral and vitamin contents, such as skim milk powder, cereal and leguminous seeds improved their nutritive value. Combination of dates with milk is considered an excellent food source that is prefect as an evening protein supplement. Because the majority of the protein in milk is casein (slow protein) which will ensure that the body has the amino acid needs to facilitate muscle recovery (Abbott Laboratories, 2009)

Milk is the natural food as a useful supply of calcium, phosphorus, vitamin $\mathrm{D}$, good quality protein and other important nutrient components (Webb et al., 1987). The gross chemical composition of skim milk powder ranged between $3-7 \%$ moisture content, $0.5-1.5 \%$ fat, $33-37 \%$ of protein, $7-9.5 \%$ ash and $48-53 \%$ lactose contents (Kirk and Sawyer, 1991).

Starch is used as an ingredient of food systems, and controlling its gelatinization is often critical in the manufacture of starch-containing foods. In dairy product applications, starch can be used as a thickener, a fat replacer or filler (Oh et al., 2009). 
The objective of this investigation was to produce new products from date and skim milk powder containing high levels of sugars, protein and minerals. These products were evaluated for quality attributes during processing and storage at room temperature.

\section{MATERIALS AND METHODS \\ 2.1. Materials}

Siwia dates (Tamr stage) were obtained from Siwia Oasis, El-Wadi El-Gidid, Egypt. Skim milk powder, Miro (protein more than $32 \%$, lactose less than $53 \%$, ash $7-9 \%$, fat less than $1.25 \%$ and moisture 3-5\%) was purchased from Tanbouli Co., Egypt. Starch was obtained from the Egyptian Glucose and Starch Company, Egypt.Thanthan and carboxy methyl cellulose were obtained from El-Gomhoria Company for Chemicals, Egypt. Packaging material (PPA) of three layers (polyethylene, polyester and aluminum foils) was provided from Nile Co., for Printing and Packing, $10^{\text {th }}$ of Ramadan City, Egypt.

\subsection{Processing methods}

\subsubsection{Production of date-skim milk powder}

Siwi dates at the tamr stage were cleaned, washed, pitted, minced and mixed with skim milk powder at a ratio of date : skim milk powder of 1 : $1,1: 2,1: 3,2: 1$ and $3: 1$ (wt : wt). Starch was added to the previous treatments at 10,20 and $30 \%$ (wt: wt). Also, thanthan was added to all mixtures at $0.5 \%$ (wt: wt) as shown in Table (1). The mixture was homogenized, then dried at $60^{\circ} \mathrm{C}$ under vacuum till moisture content was $\sim 5 \%$. The products were ground by petern laboratory mill and sieved through 0.125 mesh. The products were packed under vacuum in laminate sacs PPA packing material $(10 \times 15 \mathrm{~cm})$. To prepare dateskim milk suspension for sensory evaluation, $15 \mathrm{~g}$ of date-skim milk powder was added to $100 \mathrm{ml}$ of water then, heated and stirred during heating till the mixture was completely dissolved and suspended.

\subsubsection{Production of instant date-skim milk powder}

Date extract was prepared according to Assous (1999) as follows. Date was extracted with a ratio of date to water $1: 3$ (wt ; vol) and homogenized with a mixer for $2.5 \mathrm{~min}$. at room temperature then the mixtures were transferred into a piece of nylon cloth and pressed to recover the extract. The resultant extract quantity from date extraction was mixed with skim milk powder at ratios of 1: 1, 1: 2, 1:3, 2: 1 and 3: 1 (wt/wt) date to skim milk powder. Both carboxy methyl cellulose (CMC) and thanthan were added at 0.5 $\%$ to the mixtures as shown in Table (1), then homogenized and dried at $60^{\circ} \mathrm{C}$ under vacuum till moisture content was $\sim 5 \%$.The products were ground by a pattern laboratory mill and sieved through 0.125 mesh, then packed under vacuum in PPS sacs. To prepare instant date-skim milk syrup for sensory evaluation, $15 \mathrm{~g}$ of the instant dateskim milk powder was added to100ml of water and stirred well.

2.2.3. The selected products after statistical analysis were analyzed physical and chemical, microbial and sensory evaluation during storage at room temperature $\left(\left(25^{\circ} \mathrm{C}\right)\right.$.

\subsection{Analytical methods}

Moisture content, $\mathrm{pH}$ value, total acidity, total sugars, reducing and non- reducing sugars, starch, protein, fat and ash contents were determined according to the methods described in A.O.A.C (2000).Amino acids were determined according to the method described by Pellet and Young (1980) using a Beckman Amino Acid Analyzer Model 7300 with integrator Beckman 7000 data system. Tryptophan was determined according to Sastry and Tummuru (1985). Mineral content, sodium, potassium, calcium, magnesium, iron, copper, zinc and phosphorus were determined according to the A.O.A.O (2000). Approximate energy value was presented as calories/100g of the product calculated on the base of $1 \mathrm{~g}$ of total sugars, starch or protein equals 4.0 calories and $1 \mathrm{~g}$ of fat equals 9 calories as mentioned by Lawrence (1965).Bulk density $(\mathrm{Db})$ was measured by placing a known weight of powder in a measuring cylinder, and calculated by dividing the mass $(\mathrm{m})$ of the powder by the volume (v) of the powder as follows:

$$
\mathrm{Db}=\frac{\mathrm{m}}{\mathrm{v}}
$$

$\mathrm{Db}=$ the bulk density of the powder, $\mathrm{g} / \mathrm{cm}^{3}$

$\mathrm{m}=$ the mass of the powder, $\mathrm{g}$.

$\mathrm{v}=$ the volume of the powder, $\mathrm{cm} 3$

Moisture adsorption isotherms were determined by placing a weight of the powder in desiccators containing saturated solution of ammonium sulfite of specific equilibrium humidity (RH) $75 \%$ at $25^{\circ} \mathrm{C}$. The moisture content of the powder was determined after 2 weeks (Labuza et al., 1985).

Solubility index was determined according to Hall and Hedrick (1966).Non-enzymatic browning of the samples was determined according to the method of Ranganna (1977). Total bacterial counts as well as sporeformer counts were determined according to the method described by APHA (1992). Sensory evaluation of color, taste, odor, texture and overall acceptability of the reconstituted date-skim milk powders were evaluated according to Ranngana (1977). The results of sensory evaluation were statistically 


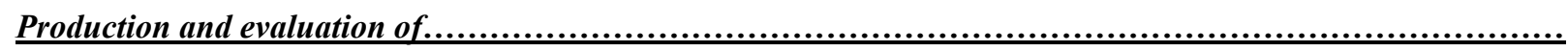

Table (1):Ingredient contents of instant and date-skim milk powder.

\begin{tabular}{|c|c|c|c|c|c|}
\hline \multirow[b]{2}{*}{ Treatments } & \multicolumn{5}{|c|}{ Formula } \\
\hline & Siwi dates & $\begin{array}{c}\text { Skim } \\
\text { milk } \\
\text { powder }\end{array}$ & $\begin{array}{c}\text { Starch }(\%) \\
(w t: w t)\end{array}$ & $\begin{array}{c}\text { Thanthan } \\
(\%)\end{array}$ & $\mathrm{CMC}(\%)$ \\
\hline & \multicolumn{5}{|c|}{ Date-skim milk powder } \\
\hline & & & & & \\
\hline $\mathrm{T} 1$ & 1 & 1 & $10,20,30$ & 0.5 & --- \\
\hline $\mathrm{T} 2$ & 1 & 2 & $10,20,30$ & 0.5 & --- \\
\hline T3 & 1 & 3 & $10,20,30$ & 0.5 & --- \\
\hline T4 & 2 & 1 & $10,20,30$ & 0.5 & --- \\
\hline \multirow[t]{2}{*}{ T5 } & 3 & 1 & $10,20,30$ & 0.5 & --- \\
\hline & \multicolumn{5}{|c|}{ Instant date-skim milk powder } \\
\hline T6 & 1 & 1 & ---- & 0.5 & 0.5 \\
\hline T7 & 1 & 2 & ---- & 0.5 & 0.5 \\
\hline T8 & 1 & 3 & ---- & 0.5 & 0.5 \\
\hline T9 & 2 & 1 & ---- & 0.5 & 0.5 \\
\hline T10 & 3 & 1 & ---- & 0.5 & 0.5 \\
\hline
\end{tabular}

Table (2):Mean score values of sensory evaluation of reconstituted instant and date-skim milk powder.

\begin{tabular}{|c|c|c|c|c|c|c|}
\hline \multicolumn{2}{|c|}{$\begin{array}{l}\text { Properties } \\
\text { Treatments }\end{array}$} & Color & Taste & Odor & Texture & $\begin{array}{c}\text { Overall } \\
\text { acceptability }\end{array}$ \\
\hline & & & \multicolumn{2}{|c|}{ Date-skim milk powder } & & \\
\hline $\mathrm{T} 1$ & (10\% starch) & $7.5^{\mathrm{abc}}$ & $9.5^{\mathrm{a}}$ & $8.5^{\mathrm{a}}$ & $7.0^{b c}$ & $8.1^{\mathrm{ab}}$ \\
\hline $\mathrm{T} 1$ & (20\% starch) & $7.5^{\mathrm{abc}}$ & $9.0^{\mathrm{ab}}$ & $8.5^{\mathrm{a}}$ & $7.5^{\mathrm{ab}}$ & $8.1^{\mathrm{ab}}$ \\
\hline $\mathrm{T} 1$ & (30\% starch) & $8.5^{\mathrm{a}}$ & $9.0^{\mathrm{ab}}$ & $8.0^{\mathrm{ab}}$ & $9.0^{\mathrm{a}}$ & $8.6^{\mathrm{a}}$ \\
\hline $\mathrm{T} 2$ & (10\% starch) & $7.5^{\mathrm{abc}}$ & $9.0^{\mathrm{ab}}$ & $8.5^{\mathrm{a}}$ & $7.0^{\mathrm{bc}}$ & $8.0^{\mathrm{ab}}$ \\
\hline $\mathrm{T} 2$ & (20\% starch) & $8.0^{\mathrm{ab}}$ & $8.5^{a b c}$ & $8.0^{\mathrm{ab}}$ & $7.5^{\mathrm{ab}}$ & $8.0^{\mathrm{ab}}$ \\
\hline $\mathrm{T} 2$ & (30\% starch) & $8.4^{\mathrm{a}}$ & $8.5^{a b c}$ & $7.8^{\mathrm{abc}}$ & $9.0^{\mathrm{a}}$ & $8.4^{\mathrm{a}}$ \\
\hline T3 & (10\% starch) & $8.0^{\mathrm{ab}}$ & $7.5^{\text {bcd }}$ & $6.5^{b c}$ & $5.0^{\text {cde }}$ & $6.7^{b c}$ \\
\hline T3 & (20\% starch) & $7.5^{a b c}$ & $7.5^{\text {bcd }}$ & $6.5^{b c}$ & $5.5^{\text {bcde }}$ & $6.7^{b c}$ \\
\hline T3 & (30\% starch) & $6.5^{\text {bcd }}$ & $7.5^{\text {bcd }}$ & $6.3^{c}$ & $7.0^{\mathrm{bc}}$ & $6.8^{\mathrm{bc}}$ \\
\hline $\mathrm{T} 4$ & (10\% starch) & $6.0^{\mathrm{bcd}}$ & $7.5^{\text {bcd }}$ & $6.9^{a b c}$ & $5.0^{\text {cde }}$ & $6.3^{c}$ \\
\hline T4 & (20\% starch) & $6.0^{\mathrm{bcd}}$ & $7.0^{\mathrm{cd}}$ & $6.5^{\mathrm{bc}}$ & $5.5^{\text {bcde }}$ & $6.2^{\mathrm{c}}$ \\
\hline $\mathrm{T} 4$ & (30\% starch) & $6.5^{\mathrm{abcd}}$ & $7.0^{\mathrm{cd}}$ & $6.5^{b c}$ & $6.0^{\text {bcde }}$ & $6.5^{\mathrm{c}}$ \\
\hline T5 & (10\% starch) & $5.0^{\mathrm{d}}$ & $7.5^{\text {bcd }}$ & $6.8^{\mathrm{abc}}$ & $4.0^{\mathrm{e}}$ & $5.8^{\mathrm{c}}$ \\
\hline T5 & (20\% starch) & $5.5^{\mathrm{cd}}$ & $7.0^{\mathrm{cd}}$ & $6.5^{b c}$ & $4.5^{\mathrm{de}}$ & $5.8^{\mathrm{c}}$ \\
\hline T5 & (30\% starch) & $6.0^{\text {bcd }}$ & $6.5^{\mathrm{d}}$ & $6.0^{\mathrm{c}}$ & $5.1^{\text {cde }}$ & $5.9^{\mathrm{c}}$ \\
\hline \multirow[t]{2}{*}{ LSD } & & 1.27 & 1.64 & 1.46 & 1.74 & 1.20 \\
\hline & \multicolumn{6}{|c|}{ Instant date-skim milk powder } \\
\hline T6 & & $9.0^{\mathrm{a}}$ & $9.0^{\mathrm{a}}$ & $8.1^{\mathrm{a}}$ & $8.5^{\mathrm{a}}$ & $8.6^{\mathrm{a}}$ \\
\hline $\mathrm{T} 7$ & & $8.5^{\mathrm{ab}}$ & $9.0^{\mathrm{a}}$ & $7.3^{\mathrm{ab}}$ & $8.5^{\mathrm{a}}$ & $8.3^{\mathrm{ab}}$ \\
\hline T8 & & $7.5^{\mathrm{abc}}$ & $7.5^{\mathrm{ab}}$ & $7.1^{\mathrm{ab}}$ & $8.5^{\mathrm{a}}$ & $7.6^{b c}$ \\
\hline T9 & & $7.0^{b c}$ & $7.5^{\mathrm{ab}}$ & $7.0^{\mathrm{ab}}$ & $7.3^{\mathrm{ab}}$ & $7.2^{\mathrm{cd}}$ \\
\hline T10 & & $6.0^{c}$ & $7.0^{b}$ & $6.5^{b}$ & $6.3^{b}$ & $6.4^{\mathrm{d}}$ \\
\hline LSD & & 1.82 & 1.73 & 1.22 & 1.89 & 0.77 \\
\hline
\end{tabular}


analyzed using Duncan's multiple range tests according to the method reported by Snedecor and Cochran (1980)

\section{RESULTS AND DISCUSSION}

\subsection{Sensory evaluation of date-skim milk} powder formulas

The studied food formulas were reconstituted, sensory evaluation in terms of color, taste, odor, texture and overall acceptability were tested and the results were statistically analyzed and recorded in Table (2).

Color scores of date-skim suspensions $\left(\mathrm{T}_{1}\right.$ and $\mathrm{T}_{2}$ ) and instant date-skim milk syrups $\left(\mathrm{T}_{6}\right.$ and $\left.\mathrm{T}_{7}\right)$ were significantly higher than those of other treatments. Also, color scores of the new products gradually decreased with increasing the ratio of date or skim milk due to increasing the brown color resulting from dates or the white color resulting from skim milk powder.

Taste scores of date-skim milk suspensions decreased with increasing the starch ratio; however, there were no significant differences between the same treatments. From the results in Table (2) it could be noticed that taste scores of the products were found to be acceptable even when the level of skim milk powder increased until 50\%. Texture scores of date-skim milk suspensions gradually increased with increasing the ratio of starch up to $30 \%$ regardless of the treatment type. The texture scores of treatments $\left(\mathrm{T}_{1}\right.$ and $\left.\mathrm{T}_{2}\right)$ with30\% starch were the highest, while the other treatments of skim milk powder were evaluated as fair. Also, it could be noticed that the texture scores of instant- date-skim milk syrups of treatments $\left(\mathrm{T}_{6}\right.$ and $\left.\mathrm{T}_{7}\right)$ were significantly higher than those of other treatments.

Odor scores showed high significant differences between treatments $\left(\mathrm{T}_{1}\right.$ and $\left.\mathrm{T}_{2}\right)$ of date-skim milk suspensions, $\left(\mathrm{T}_{6}\right.$ and $\left.\mathrm{T}_{7}\right)$ of instant date-skim milk syrups and other treatments due to odor equilibrium between date-skim milk components.

The overall acceptability scores were the highest for reconstituted date-skim milk powder prepared with $30 \%$ starch $\left(\mathrm{T}_{1}\right.$ and $\left.\mathrm{T}_{2}\right)$ and instant date-skim milk powder $\left(T_{6}\right.$ and $\left.T_{7}\right)$, thus, these formulas were selected among all to follow their quality parameters during storage.

\subsection{Physical properties of date-skim milk powder formulas}

Non-enzymatic browning was high in the products containing a ratio of date to skim milk (1:1) regardless of the product type. These results are due to high browning of used date pulp (absorbance, 0.175). Also ,the results in Table (3) showed that non enzymatic browning was higher with date-skim milk powder than that of instant date skim milk powder due to adding the hole date pulp to skim milk powder of treatments $\left(T_{1}\right.$ and $\mathrm{T}_{2}$ ) while date extracts only were added to skim milk powder in treatments $\left(\mathrm{T}_{6}\right.$ and $\left.\mathrm{T}_{7}\right)$. Nonenzymatic browning observed in the samples may be due to the reaction between reducing sugars and amino acids or organic acids during dehydration (Maier et al., 1964). Results in Table (3) indicate that bulk density of date pulp was $1.418 \mathrm{~g} / \mathrm{cm} 3$ Also, bulk density of treatments $\left(\mathrm{T}_{2}\right.$ and $\mathrm{T}_{7}$ ) at a ratio $1: 2$ of date pulp or extract: skim milk powders were higher than those of treatments $\left(\mathrm{T}_{1}\right.$ and $\mathrm{T}_{6}$ ) at a ratio $1: 1$ of date pulp or extract: skim milk powder. These results are in agreement with Deis (1997) who reported that the bulk density increased by increasing the total solid contents.

A high solubility index refers to the above normal amount of insoluble components in the date pulp (1.03), thus, solubility index was higher with date-skim milk powder $\left(\mathrm{T}_{1}\right.$ and $\left.\mathrm{T}_{2}\right)$ than that of instant date-skim milk powder $\left(\mathrm{T}_{6}\right.$ and $\left.\mathrm{T}_{7}\right)$. Also, the same Table (3) shows that solubility index was higher at a ratio of 1:1 than that of ratio 1:2 date: skim milk regardless the type of the products. These results are in agreement with those reported by Hall and Hedrick, (1966) and Bahnasawy et al. (2007). Results in Table (3) show that moisture adsorption isotherms of fresh date pulp was the highest $(6.43 \mathrm{~g}$ $\mathrm{H}_{2} \mathrm{O} / 100 \mathrm{~g}$ solids).These results are due to high reducing sugars of dates. Also, moisture adsorption isotherms was the highest for treatment $T_{6}$ while, the lowest of treatments was $\left(\mathrm{T}_{2}\right)$. This increment in moisture adsorption isotherms may be due to the high presence of reducing sugars which led to absorb the moisture (Moy et al., 1974).

\subsection{Chemical composition of date-skim milk powder formulas}

Results in Table (4) indicate that chemical composition of fresh Siwi dates were in good agreement with those reported by Ramadan (1995), Assous (1999), Khalil et al. (2002) and Sorour and Assous (2008). Results in Table (4) show that moisture content of the products ranged from 4.5 to $5.7 \%$. It could be noticed that moisture content of date-skim milk powder and instant date-skim milk powder in treatments $\left(\mathrm{T}_{1}\right.$ and $\left.\mathrm{T}_{6}\right)$ were higher than those of treatments $\left(T_{2}\right.$ and $\left.T_{7}\right)$, respectively. These results may be due to high sugars in these treatments which hold the moisture. Data also, illustrate that acidity ranged from 0.45 to $0.69 \%$ on dry weight basis. These differences may be due to the increase of the date in the formulas. Sugar contents are one of the 
Table (3): Physical properties of instant and date-skim milk powder.

\begin{tabular}{|l|l|c|c|c|c|}
\hline Treatments & Siwi dates & \multicolumn{1}{|c|}{$\begin{array}{l}\text { Date-skim milk } \\
\text { powder }\end{array}$} & \multicolumn{1}{|c|}{$\begin{array}{c}\text { Instant date- } \\
\text { skim milk } \\
\text { powder }\end{array}$} \\
\cline { 3 - 6 } & fresh & $\mathrm{T} 1$ & $\mathrm{~T} 2$ & $\mathrm{~T} 6$ & $\mathrm{~T} 7$ \\
\hline Non enzymatic browning (absorbance at 420 nm) & 0.175 & 0.356 & 0.267 & 0.198 & 0.159 \\
\hline Bulk density (g/cm3) & 1.418 & 0.729 & 0.887 & 0.753 & 0.911 \\
\hline Solubility index (ml) & 1.03 & 0.45 & 0.29 & 0.23 & 0.15 \\
\hline Moisture adsorption isotherms (gH2O/100g solids) & 6.43 & 1.64 & 1.20 & 2.39 & 1.15 \\
\hline
\end{tabular}

Table (4)Chemical composition of instant and date-skim milk powder (on dry weight basis).

\begin{tabular}{|l|c|c|c|c|c|}
\hline \multicolumn{1}{|c|}{$\begin{array}{l}\text { Treatment } \\
\text { fresh }\end{array}$} & & \multicolumn{2}{c|}{ Date-skim milk powder } & \multicolumn{2}{c|}{$\begin{array}{l}\text { Instant date-skim } \\
\text { milk powder }\end{array}$} \\
\cline { 3 - 6 } .. & & T1 & T2 & T6 & T7 \\
\hline Moisture content (\%) & 18.29 & 5.1 & 4.5 & 5.7 & 4.9 \\
\hline pH value & 5.92 & 6.21 & 6.40 & 6.41 & 6.58 \\
\hline Total acidity*(\%) (as citric acid) & 0.398 & 0.690 & 0.510 & 0.523 & 0.453 \\
\hline Total sugars*(\%) & 92.50 & 51.95 & 47.85 & 65.95 & 60.15 \\
\hline Reducing sugars*(\%) & 90.37 & 28.32 & 19.39 & 29.38 & 17.64 \\
\hline Non-reducing sugars*(\%) & 2.13 & 23.63 & 28.46 & 36.57 & 42.51 \\
\hline Starch* (\%) & --- & 23.19 & 23.07 & --- & -- \\
\hline Protein* (\%) & 2.83 & 14.38 & 18.90 & 23.57 & 27.66 \\
\hline Fat* (\%) & 1.25 & 0.71 & 0.77 & 1.02 & 1.11 \\
\hline Ash* (\%) & 2.58 & 3.92 & 4.73 & 5.89 & 7.59 \\
\hline Calorie value (cal/100g) & 392.57 & 364.47 & 366.21 & 367.26 & 361.23 \\
\hline
\end{tabular}

* On dry weight basis

most important parameters to be considered in determining the quality of formulas because it is considered the main factor of the caloric value.

Results in Table (4) indicate that the total sugars of formulas ranged from 47.85 to $65.95 \%$ (on dry weight basis) and reducing sugars represented 29.3-54.5\% of total sugars.

Protein content of formulas ranged from 14.38 to $27.66 \%$ (on dry weight basis), thus these formulas were a rich source of protein. Also, from Table (4) it could be noticed that protein content of the formulas increased with increasing the ratio of skim milk powder added to the formulas. This is due to the high protein content of skim milk powder. Fat and ash content of the formulas ranged from 0.71 to $1.11 \%$ and 3.92 to $7.59 \%$ (on dry weight basis), respectively. From these results, it could be noticed that the fat content was low while, the ash content was high due to the low fat content and high ash content of both date and skim milk powder (Ling, 1963 and El-Shewey et al., 2005).

Data reported in Table (4) show that the formulas were considered as an excellent source of available energy. The caloric value of the formulas ranged from 361.23 to $367.26 \mathrm{cal} / 100 \mathrm{~g}$.

\subsection{Amino acid content of date-skim milk powder formulas}

Results in Table (5) indicate that the predominant amino acid adhering in all the formulas were glutamic acid followed by proline, leucine and aspartic acids. Furthermore tryptophan was the lowest content in all formulas. Ahmed et al. (1995) found that the amino acid of dates revealed that proteins are rich in acidic amino acids and poor in sulphur-containing amino acids such as methionine and cysteine. Also, Webb et al. (1987) showed that the skim milk protein was the highest in glutamic acid, proline and aspartic acid. From the results in Table (5) it could be noticed that the formulas contained essential amino acids which covered high percentage of the daily allowance for human.

\subsection{Mineral content of date-skim milk powder formulas}

Results in Table (6) show that the prepared formulas are good source for many important minerals. The results show that potassium and calcium were the major minerals which ranged from 871.8 to 1424.1 and from 484.7 to 973 (mg/100g dry weight basis) respectively, followed by phosphorus content which ranged from 349.4 $772.8 \mathrm{mg} / 100 \mathrm{~g}$ dry weight basis. 
From the results in Table (6) it could be observed that the ratios of sodium: potassium of formulas ranged from $0.25: 1$ to $0.26: 1$. These results are in accordance with those resported by National Research Center (1980).

Table (5). Amino acid contents of instant and date-skim milk powder (mg/100g on dry weight basis).

\begin{tabular}{|c|c|c|c|c|}
\hline \multirow{2}{*}{ Amino acids } & \multicolumn{2}{|c|}{$\begin{array}{c}\text { Date-skim milk } \\
\text { powder }\end{array}$} & \multicolumn{2}{|c|}{$\begin{array}{c}\text { Instant date- } \\
\text { skim milk } \\
\text { powder }\end{array}$} \\
\hline & $\mathrm{T} 1$ & $\mathrm{~T} 2$ & T6 & $\mathrm{T} 7$ \\
\hline Leucine & 1263 & 1638 & 2119 & 2439 \\
\hline Isoleucine & 689 & 892 & 1136 & 1295 \\
\hline Valine & 631 & 808 & 1029 & 1162 \\
\hline Lysine & 815 & 1058 & 1354 & 1554 \\
\hline Threonine & 599 & 769 & 977 & 1103 \\
\hline Methionine & 333 & 431 & 528 & 635 \\
\hline Histidine & 287 & 362 & 440 & 553 \\
\hline Phenylalanine & 505 & 635 & 804 & 940 \\
\hline Tryptophan & 173 & 208 & 240 & 313 \\
\hline Arginine & 396 & 500 & 615 & 735 \\
\hline Alanine & 470 & 585 & 740 & 860 \\
\hline Aspartic acid & 1131 & 1462 & 1880 & 2103 \\
\hline Tyrosine & 780 & 1021 & 1302 & 1503 \\
\hline Glycine & 321 & 388 & 531 & 572 \\
\hline Proline & 1608 & 2332 & 2466 & 3152 \\
\hline Serine & 842 & 1092 & 1395 & 1605 \\
\hline Glutamic acid & 2872 & 3634 & 4528 & 5582 \\
\hline
\end{tabular}

3.6. Effect of storage period at room temperature on the physical and chemical properties of date-skim milk powder formulas.

Non-enzymatic browning (absorbance at 420 $\mathrm{nm}$ ) was gradually and slightly increased during storage. This result could be attributed to browning reactions between sugars and amino acids as reported by Bolin and Steele (1987) and Nezam-El-Din and Abd-El-Hameed (2003).

Also, solubility index slightly increased during storage. The increase of denaturation is directly correlated to the high moisture content and extending time of storage (Hall and Hedrick, 1966 and Mohamed 1996).

Moisture content of date-skim milk powder formulas slightly increased by $2.24-5.04 \%$ of its original value after 9 months of storage. This increase of moisture content may be related to the high level of reducing sugars in the products that catch some water from the permeability packaging materials during storage.

Results in Table (7) reveal that total sugar contents of the products slightly decreased during storage. This decrement could be due to reducing sugar reaction with amino acids (Mattuk et al., 1997). Also, from the same Table (7) it could be observed that non-reducing sugar contents slightly decreased and was accompanied by an ages increase in reducing sugars content of the products

Table (6).Minerals content of instant and date-skim milk powder (mg/100g dry weight basis).

\begin{tabular}{|c|c|c|c|c|}
\hline Treatment & $\begin{array}{r}\text { Date-s } \\
\text { po }\end{array}$ & milk & $\begin{array}{r}\text { Insta } \\
\text { mil }\end{array}$ & $\begin{array}{l}\text { ate-skim } \\
\text { owder }\end{array}$ \\
\hline Element & $\mathrm{T} 1$ & $\mathrm{~T} 2$ & T6 & T7 \\
\hline Sodium & 218.5 & 252.5 & 347.6 & 376.6 \\
\hline Potassium & 871.8 & 989.9 & 1342. & 1424.1 \\
\hline Calcium & 484.7 & 635.5 & 825.8 & 973 \\
\hline Magnesium & 53.76 & 56.2 & 59.1 & 65.9 \\
\hline Iron & 0.66 & 0.51 & 0.78 & 0.58 \\
\hline Cupper & 0.10 & 0.12 & 0.11 & 0.16 \\
\hline Zinc & 1.29 & 1.58 & 1.17 & 1.65 \\
\hline phosphorus & 349.4 & 514.7 & 673.9 & 772.8 \\
\hline
\end{tabular}

during storage.

With respect to the effect of storage on the protein contents, it could be noticed that these contents slightly decreased in all products. These decrements could be attributed to the gradual autolysis of protein during the storage period (Abo-Zaid, 2002).

\subsection{Effect of storage period at room temperature on microbial counts of date- skim milk powder formulas}

Results in Table (8) show that total bacterial and sporeform counts gradually decreased during storage at room temperature. These results are in the same trend that was reported by Salama (2000) and Bekheit (2002). It could be noticed that the total bacterial and sporeform counts in $\mathrm{T}_{2}$ and $\mathrm{T}_{7}$ were higher than that of $T_{1}$ and $T_{6}$. These results may be due to higher protein content and low acidity of these treatments than the other treatments. Generally, the microbial counts of the formulas were less than the standard plate count of all grades of dry milk products (Hall and Hedrick (1966).This could be attributed to the low moisture content as well as the good sanitation during processing,packaging under vacuum and type of packaging material.

\subsection{Effect of storage period at room}

temperature on sensory evaluation of dateskim milk powder formulas

Results in Table (9) show that mean scores of sensory evaluation of all products were decreased by storage but the values of $\mathrm{T}_{1}$ and $\mathrm{T}_{7}$ were declined higher than that of $\mathrm{T}_{1}$ and $\mathrm{T}_{6}$. However, the mean scores of all products were higher than that of 6.8 scores 


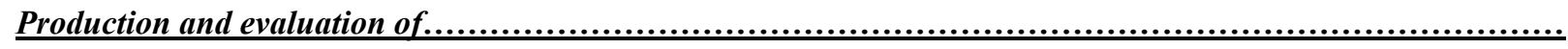

Table (7).Effect of storage period at room temperature on physical and chemical characteristics of date-milk formulas.

\begin{tabular}{|c|c|c|c|c|c|c|c|c|}
\hline \multirow{3}{*}{$\underbrace{\text { Storage period (month) }}_{\text {Properties }}$} & \multicolumn{8}{|c|}{ Date-skim milk powder } \\
\hline & \multicolumn{4}{|c|}{ T1 } & \multicolumn{4}{|c|}{$\mathbf{T 2}$} \\
\hline & $\begin{array}{l}\text { Zero } \\
\text { time }\end{array}$ & 3 & 6 & 9 & $\begin{array}{l}\text { Zero } \\
\text { time }\end{array}$ & 3 & 6 & 9 \\
\hline Non-enzymatic browning (ab.420nm) & 0.356 & 0.372 & 0.383 & 0.386 & 0.267 & 0.277 & 0.283 & 0.287 \\
\hline Solubility index & 0.45 & 0.47 & 0.48 & 0.50 & 0.29 & 0.30 & 0.30 & 0.31 \\
\hline $\mathrm{pH}$ & 6.21 & 6.24 & 6.27 & 6.30 & 6.40 & 6.43 & 6.46 & 6.48 \\
\hline Moisture content $(\%)$ & 5.10 & 5.21 & 5.27 & 5.33 & 4.50 & 4.56 & 4.61 & 4.66 \\
\hline Acidity* $(\%)($ as citric acid $)$ & 0.690 & 0.683 & 0.676 & 0.665 & 0.511 & 0.505 & 0.50 & 0.495 \\
\hline Total sugars* $(\%)$ & 51.95 & 51.32 & 51.20 & 50.91 & 47.85 & 47.71 & 47.53 & 47.28 \\
\hline Reducing sugars* $(\%)$ & 28.32 & 28.74 & 29.31 & 29.73 & 19.39 & 19.58 & 19.93 & 20.16 \\
\hline Non-reducing sugars* $(\%)$ & 23.63 & 22.58 & 21.89 & 21.18 & 28.46 & 28.13 & 27.60 & 27.12 \\
\hline $\operatorname{Starch}^{*}(\%)$ & 23.19 & 22.95 & 22.79 & 22.61 & 23.07 & 22.86 & 22.72 & 22.61 \\
\hline \multirow[t]{3}{*}{ Protein* $(\%)$} & 14.38 & 14.27 & 14.17 & 14.09 & 18.90 & 18.84 & 18.74 & 18.66 \\
\hline & \multicolumn{8}{|c|}{ Instant date-skim milk powder } \\
\hline & \multicolumn{4}{|c|}{ T6 } & \multicolumn{4}{|c|}{ T7 } \\
\hline Non-enzymatic browning (ab.420nm) & 0.198 & 0.208 & 0.213 & 0.216 & 0.159 & 0.163 & 0.166 & 0.168 \\
\hline Solubility index & 0.23 & 0.23 & 0.24 & 0.25 & 0.15 & 0.15 & 0.16 & 0.16 \\
\hline $\mathrm{pH}$ & 6.41 & 6.42 & 6.45 & 6.48 & 6.58 & 6.58 & 6.60 & 6.61 \\
\hline Moisture content $(\%)$ & 5.69 & 5.81 & 5.92 & 5.98 & 4.91 & 4.94 & 4.97 & 5.02 \\
\hline Acidity* $(\%)($ as citric acid $)$ & 0.523 & 0.517 & 0.513 & 0.507 & 0.453 & 0.448 & 0.444 & 0.442 \\
\hline Total sugars* $(\%)$ & 65.95 & 65.62 & 65.21 & 64.96 & 60.15 & 60.01 & 59.33 & 59.55 \\
\hline Reducing sugars* $(\%)$ & 29.38 & 29.82 & 30.26 & 30.70 & 17.64 & 17.81 & 17.90 & 18.17 \\
\hline Non-reducing sugars* $(\%)$ & 36.57 & 35.80 & 34.95 & 34.26 & 42.51 & 42.20 & 41.43 & 41.38 \\
\hline Protein $*(\%)$ & 23.57 & 23.45 & 23.33 & 23.21 & 27.66 & 27.52 & 27.45 & 27.38 \\
\hline
\end{tabular}

- $\quad$ On dry weight basis

Table (8).Total bacterial counts $\left(\mathrm{X} \mathbf{1 0}^{3} \mathrm{cfu} / \mathrm{g}\right)$ and sporeform counts (X $\left.10 \mathrm{cfu} / \mathrm{g}\right)$ of instant and dateskim milk powder after processing and during storage (at room temperature).

\begin{tabular}{|c|c|c|c|c|c|}
\hline \multirow{4}{*}{ Properties } & \multicolumn{3}{|c|}{ Date-skim milk powder } & \multicolumn{2}{c|}{$\begin{array}{c}\text { Instant date-skim milk } \\
\text { powder }\end{array}$} \\
\cline { 2 - 6 } & $\begin{array}{c}\text { Storage } \\
\text { period } \\
\text { (month) }\end{array}$ & T1 & T2 & T6 & T7 \\
\hline \multirow{4}{*}{$\begin{array}{c}\text { Total bacterial } \\
\text { counts }\end{array}$} & Zero time & 44.6 & 54.0 & 32.5 & 37.5 \\
\cline { 2 - 6 } & 3 & 41.1 & 50.4 & 29.6 & 34.6 \\
\cline { 2 - 6 } & 6 & 35 & 44.8 & 24.9 & 30.0 \\
\hline \multirow{3}{*}{$\begin{array}{c}\text { Sporeforms } \\
\text { counts }\end{array}$} & 9 & 29.1 & 38.7 & 20.20 & 25.01 \\
\cline { 2 - 6 } & Zero time & 49 & 52.5 & 34.2 & 37.3 \\
\cline { 2 - 6 } & 3 & 42.4 & 46.6 & 28.8 & 32.4 \\
\cline { 2 - 6 } & 9 & 34.18 & 39.8 & 22.6 & 26.2 \\
\hline
\end{tabular}




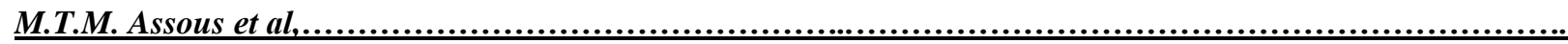

Table (9).Mean sensory scores of reconstitute date-skim milk formulas during storage.

\begin{tabular}{|c|c|c|c|c|c|c|c|c|c|}
\hline \multirow{3}{*}{ Properties } & \multicolumn{8}{|c|}{ Date-skim milk powder } & \multirow{3}{*}{ L.S.D } \\
\hline & \multicolumn{4}{|c|}{ T1 } & \multicolumn{4}{|c|}{$\mathbf{T 2}$} & \\
\hline & $\begin{array}{l}\text { Zero } \\
\text { time }\end{array}$ & 3 & 6 & 9 & $\begin{array}{l}\text { Zero } \\
\text { time }\end{array}$ & 3 & 6 & 9 & \\
\hline Color & $8.5^{\mathrm{a}}$ & $7.6^{\mathrm{ab}}$ & $7.6^{\mathrm{ab}}$ & 7.4 & $8.4^{\mathrm{a}}$ & $7.7^{\mathrm{ab}}$ & $7.5^{\mathrm{ab}}$ & $7.0^{\mathrm{b}}$ & 0.71 \\
\hline Taste & $9.0^{\mathrm{a}}$ & $8.5^{\mathrm{ab}}$ & $8.2^{\mathrm{ab}}$ & 8.0 & $8.5^{\mathrm{ab}}$ & $8.1^{\mathrm{ab}}$ & $7.8^{\mathrm{ab}}$ & $7.6^{\mathrm{ab}}$ & 0.86 \\
\hline Flavor & $8.0^{\mathrm{a}}$ & $7.5^{\mathrm{ab}}$ & $7.5^{\mathrm{ab}}$ & 7.3 & $7.8^{\mathrm{ab}}$ & $7.3^{\mathrm{ab}}$ & $7.2^{\mathrm{ab}}$ & $7.1^{b}$ & 0.76 \\
\hline Texture & $9.0^{\mathrm{a}}$ & $8.5^{\mathrm{ab}}$ & 8.22 & 8.2 & $9.0^{\mathrm{a}}$ & 8.26 & $8.3^{\mathrm{ab}}$ & $8.0^{b}$ & 0.75 \\
\hline \multirow[t]{3}{*}{ Overall acceptability } & $8.6^{\mathrm{a}}$ & $8.02^{\mathrm{abc}}$ & $7.8^{b c}$ & $\begin{array}{l}7.7 \\
\mathrm{bc}\end{array}$ & $8.4^{\mathrm{ab}}$ & $7.8^{b c}$ & $7.7^{b c}$ & $7.4^{\mathrm{c}}$ & 0.68 \\
\hline & \multicolumn{9}{|c|}{ Instant date-skim milk powder } \\
\hline & \multicolumn{4}{|c|}{ T6 } & \multicolumn{5}{|c|}{$\mathbf{T 7}$} \\
\hline Color & $9.0^{\mathrm{a}}$ & $8.4^{\mathrm{ab}}$ & $8.0^{\mathrm{bc}}$ & 7.8 & $8.5^{\mathrm{ab}}$ & $8.3^{\mathrm{abc}}$ & $7.8^{\mathrm{bc}}$ & $7.7^{b c}$ & 0.78 \\
\hline Taste & $9.0^{\mathrm{a}}$ & $8.5^{a b}$ & $8.2^{a b c}$ & $\begin{array}{l}7.9 \\
h c\end{array}$ & $9.0^{\mathrm{a}}$ & $8.4^{\mathrm{ab}}$ & $8.3^{a b c}$ & $7.8^{b c}$ & 0.72 \\
\hline Flavor & $8.1^{\mathrm{a}}$ & $7.7^{\mathrm{ab}}$ & $7.5^{\mathrm{ab}}$ & 7.3 & $7.3^{\mathrm{ab}}$ & $7.2^{\mathrm{ab}}$ & $7.0^{\mathrm{b}}$ & $6.8^{\mathrm{b}}$ & 0.81 \\
\hline Texture & $8.5^{\mathrm{a}}$ & $8.4^{\mathrm{ab}}$ & $8.1^{\text {ab }}$ & 8.1 & $8.5^{\mathrm{a}}$ & $8.5^{\mathrm{a}}$ & $8.2^{\mathrm{ab}}$ & $7.8^{a b}$ & 0.67 \\
\hline Overall acceptability & $8.65^{\mathrm{a}}$ & $8.25^{\mathrm{ab}}$ & $\begin{array}{c}7.95 \\
\mathrm{ab}\end{array}$ & $\begin{array}{c}7.77 \\
b\end{array}$ & $8.3^{\mathrm{ab}}$ & $8.1^{\mathrm{ab}}$ & $7.82^{b}$ & $7.5^{b}$ & 0.73 \\
\hline
\end{tabular}

Means with the same letter are not significantly different at 0.05 level of significance.

after 9 month of storage at room temperature indicating superior quality, Hence it could be recommended to produce instant and date-skim milk powder from date or extract date and skim milk powder at a ratio1:1 or1 :2 to give excellent product for children and other ages.

\section{Conclusion}

It can be concluded that date skim milk powder is a better combination not only for its sensory evaluation, but also because its nutritional value. Moreover, it provides high quality protein, sugars and minerals which could aid in alleviating malnutrition in developing countries.

\section{REFERENCES}

Abbott Laboratories (2009). Abbott Park ,Illioio, www.bodyforlife.com./mutation/articates.as $\mathrm{p}$ ?cmsld $=$

Abo-Zaid M.S. (2002). Chemical and Technological Studies on Using Some Date Varieties for Producing Some Balanced Foods. M.Sc. Thesis. Food Sci. and Tech. Dept., Fac. of Agric., AlAzhar Univ., Egypt.

Ahmed I.S.A., Al-Gharibi K.N., Daar A.S. and Kabir S. (1995). The composition and properties of date proteins. Food Chemistry, 53, 441-446.

Al-Hooti S.N., Sidhu J.S., Al-Saqer J.M. and AlOthman A. (2002). Chemical composition and quality of date syrup as affected by pectinase/cellulose enzyme treatment. Food Chemistry, 79, 215-220.

APHA (1992). Standard methods for the examination of dairy product. American public Health Association. Inc. $16^{\text {th }}$ Ed., Washington, D.C.

A.O.A.C. (2000). Official Method of Analysis of the Association of Official Analytical Chemists International. Published by the Association of Official Analytical Chemist's International. Maryland 20877-2417.USA.

Assous M.T.M. (1999). Production and Evaluation of Siwi Date Syrup (Dibis). M.Sc. Thesis, Food Sci and Technol. Dept., Fac. of Agric., Cairo Univ., Egypt.

Bahnasawy A.H., Okasha A.E. and Gonbeej E.E. (2007). Spray drier functional parameters and their effects on physical, chemical and structural properties of some milk-juice blends. Proc.10 ${ }^{\text {th }}$ Egyptian Conf. Dairy Sci. and Tech., 151-166. Egypt.

Bekhit A.A. (2002). Production and Evaluation of Egyptian Date Sheets and Pastes. M.Sc. Thesis, Food Sci. and Tech. Dept., Fac. of Agric, Cairo Univ., Egypt.

Bolin H. R. and Steele R.J. (1987). Nonenzymatic browning in dried apples during storage. J. of Food Sci., 52(6) 1654-1657.

Deis R.C. (1997). Spray drying innovative use of an old process. Food product Design. 7(2): 97-111.

Elleuch M., Besbes S., Roiseux O., Blecker C., Deroanne C., Drira N. and Attia H. (2008). 
Date flesh: chemical composition and characteristics of the dietary fiber. Food Chemistry, 111, 676-682.

El-Shewey M.A., Nassef A.E., Allam S.O. and Abd El-Salam S.M. (2005). Fortification of some type of biscuits with iron-rich plant additives. Egypt. J. Agric. Res., 83 (4): 1741-1754.

Hall C.W. and Hedrick T.I. (1966). Drying of Milk and Milk Powder. AVI Publish. Co., New York.

Khalil K.E., Abd-El-Bari M.S., Hafiz N.E. and Ahmad E.Y. (2002).Production, evaluation and utilization of date syrup concentrate (Dibis). Egypt. J. Food Sci., 30(2): 179-203.

Kirk R.S. and Sawyer R. (1991). Pearson's Composition and Analysis of Foods. Longman and Scientific Technical, Ninth Edition, England. pp. 566.

Labuza T.P., Kannane A. and Chen J.Y. (1985). Effect of temperature on the moisture sorption isotherms and water activity shift of two dehydrated foods. J. Food Sci., 50:385-391.

Lawrence R.D. (1965). The Diabetic Life. J. and A. Churchill, Ltd, Publisher, London.

Ling E.R. (1963). Dairy Chemistry. Text Book vol., 2, $3^{\text {rd }}$ Ed., Chapman and Hall Ltd., London.

Maier V.P., Metzer D.M. and Huber A.F. (1964). Effect of heat processing on the properties of dates. Date Geower's Inst. Ann. Rep., 41:8-9.

Mattuk H.L., Ahmed A.H., Hamed H.S. and ElSaidawy M.H. (1997). Production and evaluation of guava powder. Egypt. J. Appl. Sci., 12(5): 195-216.

Mohamed E.F. (1996).Technological Studies on Acidophilus Milk. Ph.D.Thesis, Dairy Sci. Dept., Fac. of Agric., Ain Shams Univ., Egypt.

Moy J.H., OH H.I. and Gavino V. (1974). The effects of sucrose and calcium salts on the hygroscopicity of vacuum-puff freeze-dried mango and guava nectars. Food Sci., and Tech., 11, 36-42.

National Research Center (1980). Recommended Dietary Allowance. Ed. $9^{\text {th }}$ P. 57 Food and Nutrition Board, Washington, DC, National Academy of Science, USA.
Nezam El-Din A.M. and Abd El-Hameed A.K. (2003). Production of khalal date powder. Processing of the International Conference on Date Palm and Joint Events, Kingdom of Saudi Arabia, p. 87-101.

Oh H.E., Anema S.C., Pinder D.N. and Wong M.(2009). Effects of different components in skim milk on high-pressure-induced gelatinization of waxy rice starch and normal rice starch. Food Chemistry, 113, 18.

Pellet L.P. and Young R.V. (1980). Nutritional evaluation of protein in feeds. The united Univ. WHTR.3/UNDP. 129, Tokyo.

Ramadan B.R. (1995). Biochemcal, Nutritional and Technological Studies on Dates. Ph.D. Thesis, Food Sci. Tech. Dept., Fac. of Agric., Assuit Univ., Egypt.

Ranganna S. (1977). Manual of Analysis of Fruit and Vegetable Products. Tata McGraw-Hill Publishing Company Limited, New Delhi.

Salama A. (2000). Papaya dried sheet. The $3^{\text {rd }}$ Conference of " The Food Industry at the Service of Tourism" Egypt, p. 141-154.

Sastry C.S.P. and Tummuru M.K. (1985). Spectrophotometric determination of tryptophan in protein. J. Food Sci., Tech., 22: 146-147.

Snedecor G.W. and Cochran W.G. (1980). Statistical Methods. $7^{\text {th }}$ Ed. Iowa Univ. Press Ames, Iowa, USA.

Sorour M. A. and Assous M.T. (2008). Effect of mixing during extraction on the quality of date juice. J. of Engineering and Applied Science, 55(1): 93-108.

Vandercook C.E., Hasegawa S. and Maier V.P. (1979). Quality and nutritive value of dates as influenced by their chemical composition. Date Growers' Institute, 54:311.

Webb B.H., Johnson A.H. and Alford J.A. (1987). Fundamentals of Dairy Chemistry. CBS Publishers and Distributors, India.

Yousif A.K., Benjamin N.D., Shefa M. A.I. and Ali S.M. (1976). Nutritive value of commercial Iraq date cultivars. I. Chemical composition. Tech. Bull. of Palms and Dated Research Center. No. 7, Bagdad, Iraq, Mimeographted..12pp. 


\section{إنتاج وتقييم مسحوق التمر باللبن منزوع الدهن}

مصطفى طه محمدى عسوس ، نعمة رائف عطالله”، ايمان فؤاد محمد

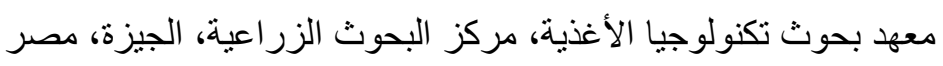

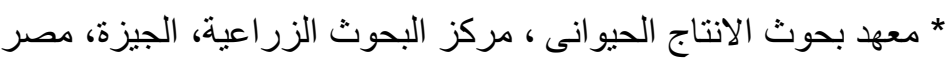

\section{ملخص}

تهدف الدراسة إلى إنتاج مسحوق من التمر واللبن الفرز غنى بالسكريات والبروتينـات و العناصر المعدنيـة بالإضـافة

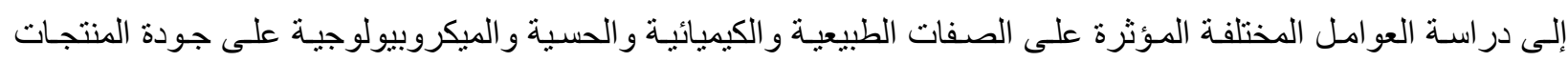
الناتجة بعد التصنيع و أثناء التخزين. أوضحت النتائج أن أفضـل الخلطـات كانت بنسبة 1: 1 و 1 : 2 مـن التمـر أو عصبر التمـر : اللبن منزوع اللدهن

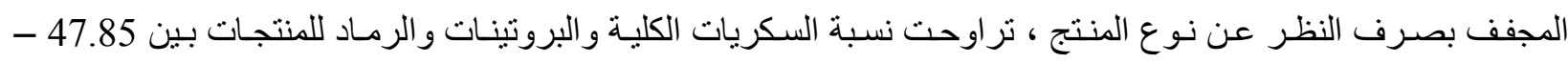

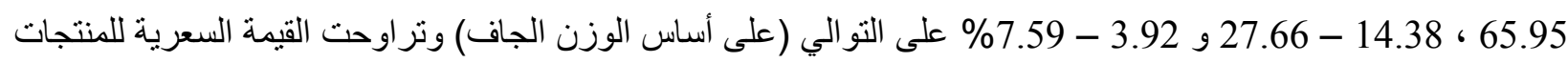
من 361.23 إلى 367.26 سعر /100جم.

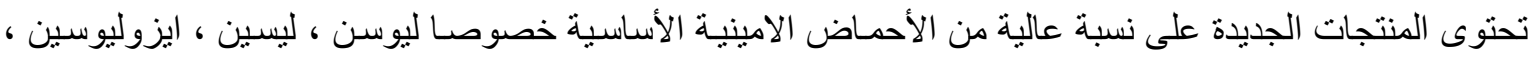

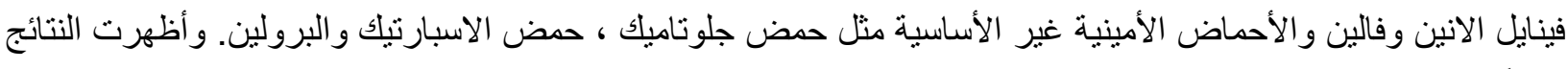

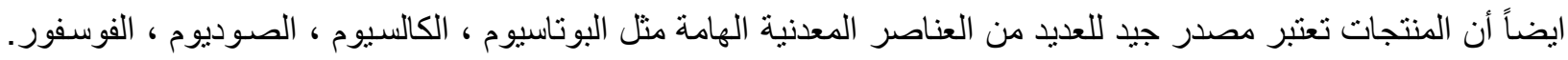

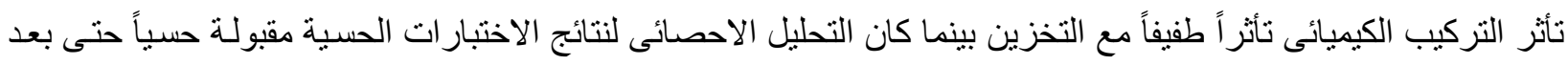
9 شهور من التخزين.

المجلة العلمية لكلية الزراعة ـ جامعة القاهرة ـ المجلد (60) العدد الثالث (يولية2009):305-296. 